\title{
Palm Oil Processing and Controversies over Its Health Effect: Overview of Positive and Negative Consequences
}

\author{
Markos Makiso Urugo ${ }^{1,2 *}$, Tilahun A. Teka ${ }^{2}$, Paulos Getachew Teshome ${ }^{3}$, and \\ Tadele Tuba Tringo ${ }^{4}$ \\ ${ }^{1}$ Department of Food Science and Postharvest Technology, College of Agricultural Sciences, Wachemo University-667, ETHIOPIA \\ ${ }^{2}$ Department of Post Harvest Management, College of Agriculture and Veterinary Medicine, Jimma University-307, ETHIOPIA \\ ${ }^{3}$ Center for Food Science and Nutrition, College of Natural Sciences, Addis Ababa University-1176, ETHIOPIA \\ ${ }^{4}$ Department of Food Technology and Process Engineering, College of Engineering and Technology, Arbaminch University, ETHIOPIA
}

\begin{abstract}
Palm oil is the world's most commonly used vegetable oil and extracted both from fruit and seed of palm tree. However, its high saturated fatty acid content raised controversies over consumption of the oil. Few scientific findings suggest it as a risk factor for cardiovascular disease and increased consumer's awareness over healthy diet raised claim over it. So that, this article aimed to review literatures on palm oil extraction process and its positive and negative health consequences and besides suggest strategies for healthy diet. Literature search of relevant articles was conducted by using Google scholar, PubMed, Web of science, MEDLINE, World Health Organization library online catalogue, UNICEF library, Open access thesis and dissertations published between 2009 and 2021 explored. Study reports recommend that palmitic acid from vegetable source has less effect on blood total cholesterol and low density lipoprotein cholesterol level as compared to palmitic acid from animal source. In contrary tocotrienols of palm oil lowers blood bad cholesterol level by $\mathbf{7 - 3 8 \%}$. Moreover, palm oil triglyceride arrangement does not have a cardiovascular risk and evidences from available in vitro and in vivo studies are not sufficient enough to conclude palm oil as a causative agent for cardiovascular disease. For healthy diet consumers should avoid trans fatty acids, solid and semi solid oils. Finally, further studies recommended on mitigation strategies to minimize process induced toxicants of palm oil to acceptable level.
\end{abstract}

Key words: palm oil, cardiovascular disease, saturated fatty acids, palmitic acid, palm olein

\section{Introduction}

Palm (Elaeis guineensis) is perennial monocotyledon plant classified under family Arecaceae. Its name derived from a Greek word "Élaeis" mean olive, as a result of palm fruit shape similarity with olive and "Guineensis" refers to the fact that the plant is native to the Gulf of Guinea. It widely grows in the tropical wetlands of the world, particularly in Asia, Latin America and Africa ${ }^{1}$. Palm trees grow up to 30 meters tall and produce a big, compact and spherical bunches of fruits. A single tree contains up to 2,000 fruits and it is known to contain high amount of beta-carotene and reddish in color. The plant is good source of edible oil and each palm fruit contains $30-35 \%$ of oil ${ }^{2}$. The oil extracted from both the fruit and the seed as a crude palm oil (CPO) from the outer mesocarp and palm-kernel oil from the endosperm ${ }^{3)}$.

Abbreviations: CPO; Crude Palm Oil, EVOO; Extra Virgin Olive Oil, FFA; Free Fatty Acid, GE; Glycidol Esters, GMO; Genetically Modified Organism, FHSBO; Fully Hydrogenated Soybean Oil, HDL-C; High Density Lipoprotein Cholesterol, HOSBO; High Oleic Soybean Oil, HPO; Hybrid Palm Oil, LDL-C; Low Density Lipoprotein Cholesterol, MCPDE; Monocholoro Propane Diol Ester, OPP; Oil Palm Phenolics, PC; Phosphatidyl Choline, PI; Phosphatidyl Inositol, PKO; Palm Kernel Oil, RBD; Refined Bleached Deodorized, SD; Sprague Dawley, sn; Steriospecific number, TAGs; Triacylglycerols, TC; Total Cholesterol

*Correspondence to: Markos Makiso Urugo, Department of Food Science and Postharvest Technology, College of Agricultural Sciences, Wachemo University-667, ETHIOPIA

E-mail: markosmakiso@gmail.com

Accepted July 29, 2021 (received for review May 7, 2021)

Journal of Oleo Science ISSN 1345-8957 print / ISSN 1347-3352 online

http://www.jstage.jst.go.jp/browse/jos/ http://mc.manusriptcentral.com/jjocs

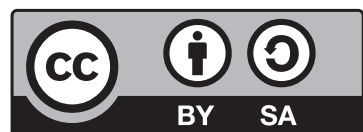


Palm oil is the world's most commonly used vegetable oils, and present in around half of frequently used food and consumer products, from snacks to cosmetics ${ }^{4}$. In 2020/2021, 75 million metric tons palm oil is produced globally; Indonesia and Malaysia are the leading producers and followed by Thailand and Colombia. From Africa Nigeria and Cote d'Ivoire are the largest producers of palm oil $^{5,6)}$. In terms of its consumption in 2019/2020, global palm oil consumption is over 73 million metric tons ${ }^{5)}$. In Ethiopia, 95\% of the total edible oil consumption is covered by import and the highest share is covered by palm oil. In 2018 calendar year, Ethiopia imported cooking oils valued around $\$ 550$ million and $88 \%$ of this value was for palm oil that imported from Malaysia and Indonesia ${ }^{7}$.

Palm oil is known to have high amount of antioxidants such as carotenoids in the range of 500-700ppm, tocopherols and tocotrienols in the range of $600-1200 \mathrm{ppm}^{8,9}$. Furthermore, study findings related to the nutritional value of the oil addressed micronutrient and fatty acid composition of both palm and kernel oil. They differ in their fatty acid proportion, particularly in saturated and unsaturated fatty acids. This variation is potentially proposed for the differential effects on lipids, lipoprotein metabolism and several aspects of health. Palm oil contains $44 \%$ palmitic acid and $4.5 \%$ stearic acid from the saturated fatty acids. In addition, it is known to contain unsaturated fatty acids such as monounsaturated fatty acid like oleic acid, 39\% and from polyunsaturated fatty acids $10 \%$ is linoleic acid. While palm kernel oil is known to have $82 \%$ saturated fatty acids such as lauric acid, myristic acid and palmitic acid at $47.8 \%, 16 \%$ and $8.5 \%$, respectively. Unsaturated fatty acids composition of palm kernel oil is $15 \%$ oleic acid and $3 \%$ of linoleic acid ${ }^{10,11)}$.

Different scientific study findings recommend consumption of palm oil as a result of its nutritional, antioxidant and various therapeutic benefits of palm oil ${ }^{1,11,12)}$. In contrary, other findings oppose the idea and associate high saturated fat content of palm oil with negative health impacts ${ }^{13,14)}$. In 2003, the World Health Organization(WHO) and Food and Agriculture Organization(FAO) depicted evidences regarding the effect of saturated fat consumption and increased risk of cardiovascular disease ${ }^{15)}$. Consequently, the WHO recommends total trans-fatty acids should not exceed 1\% of the total energy of the diet ${ }^{16)}$. Nevertheless, in Ethiopia the problem of coronary heart disease cases doubled from 1990 to 2017 and dietary risk factor is the leading problem associated with increase in the magnitude of cardiovascular disease in the country and it accounts $28 \%$, especially high saturated fat consumption of palm oil attributed ${ }^{17,18}$. Furthermore, nowadays increased consumers awareness over healthy diet raised controversy over consumption of palm oil. So, that this article intended to review recent literatures on palm oil extraction process and controversies over its health impact both positive and negative health conse- quences.

\section{Methodology}

Literature search of relevant articles was conducted by using, Google scholar, PubMed, Web of science, MEDLINE, World Health Organization library online catalogue (WHOLIS), UNICEF library, Open Access Thesis and Dissertation, published between 2009 and 2021 explored by using the following key words 'palm oil', 'palm oil and cardiovascular disease', 'palm oil and health', 'coronary heart disease and palm oil', palm olein and cardiovascular disease, palm olein and cancer. Studies that support or oppose the health benefits of palm oil were summarized. Additionally, references of each selected publications examined to get more relevant articles.

\section{Results}

\subsection{Palm tree}

Palm tree (Elaeis guineensis) is perennial monocotyledon plant classified under family Arecaceae. There are 2600 species of palm trees are grouped into 200 genera. Its name derived from a Greek word "Élaeis" mean olive, since the fruit of palm plant is identical in shape to olive and "Guineensis" refers to the fact that the plant is native to the gulf of Guinea. Genus Elaeis contains two species of palm plants, namely E. guineensis or it is also called as the Africans or oil palm, native to tropical Africa and the second species is known as the Amazonian or E. oleifera or $E$. melanococca ${ }^{1)}$. The tree grows at tropical rainforest with annual rainfall of 1780-2280 $\mathrm{mm}$ and a temperature range of $24-30^{\circ} \mathrm{C}$ (minimum and maximum) and it doesn't grow at a temperature below $15^{\circ} \mathrm{C}^{3)}$. Wildly grows in the tropical wetlands of the world, particularly in Asia, Latin

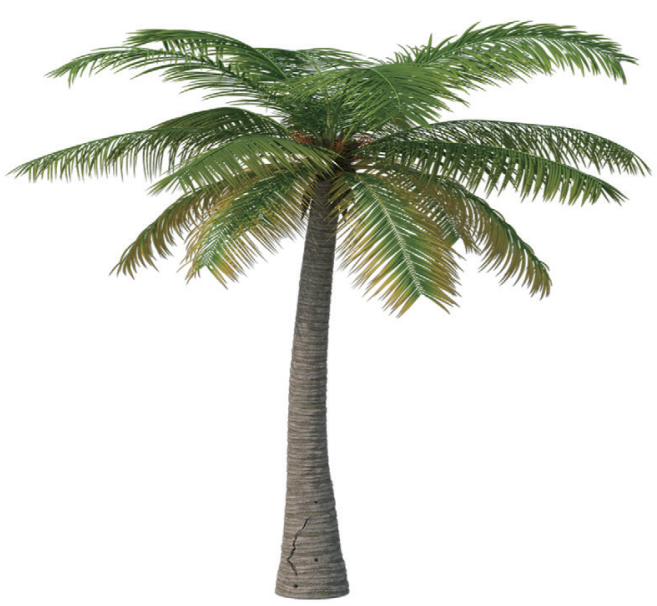

Fig. 1 Palm tree. 
America and Africa ${ }^{1)}$. Palm trees grow up to 30 meters tall as shown above on Fig. 1 and produce a big, compact and spherical bunches of fruits. The palm plant is rich source of edible oil and each palm fruit contains 30-35\% of oil ${ }^{2}$. The oil extracted from both the fruit and the seed, crude palm oil (CPO) from the fleshy outer mesocarp and palm-kernel oil from the endosperm ${ }^{3)}$.

\subsection{Palm fruit}

The fruit requires around 5 to 6 months to fully growing $^{19)}$. Depicted below on Fig. 2 a single palm tree contains up to 2,000 fruits and it is known to contain high amount of beta-carotene and reddish in color. Each fruit is about $3.5 \mathrm{~cm}$ long and $2 \mathrm{~cm}$ wide, and weighs about $3.5 \mathrm{~g}$. As indicated below on Fig. 3 palm fruit comprises three layers, the outer exocarp (the skin), oily flesh or mesocarp outer pulp containing palm oil and endocarp a hard shell that enclose the kernel(the endosperm) that contains oil and carbohydrate reserved for the embryo ${ }^{20)}$.

\subsection{Palm oil processing}

Palm oil extracted both from the fleshy part of palm fruit known (mesocarp) and from palm seed kernel called endosperm $^{1)}$. Extraction of the oil from both parts of the plant

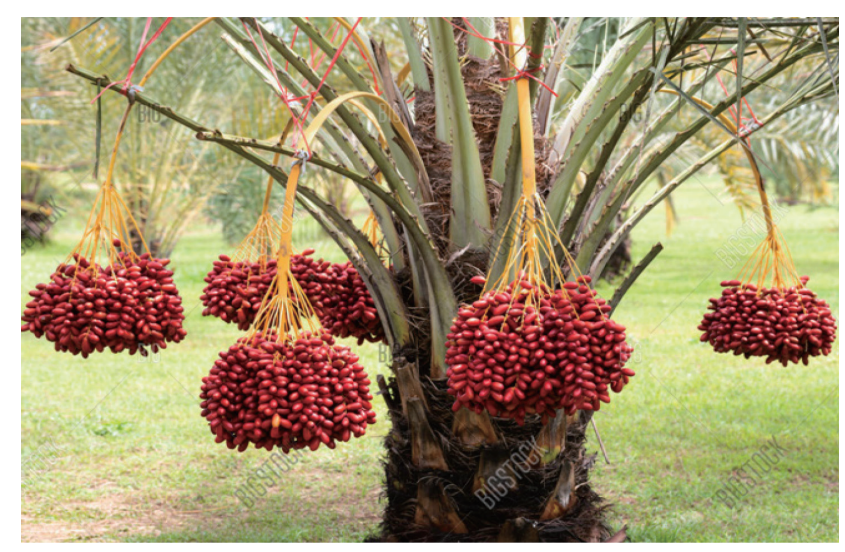

Fig. 2 Palm plant with fruit. requires different unit operations until the crude palm oil is obtained. Detail palm oil processing steps elaborated as follows.

3.3.1 Extraction of oil from palm flesh(Mesocarp)

Mesocarp of palm fruit contains $56-70 \%$ oil while the fruit fully ripe. Oil winning process involves reception of fresh fruit bunches from the plantations, sterilizing and threshing bunches to free the palm fruit, mashing the fruit and pressing out the crude palm oil ${ }^{9)}$. Detail extraction process indicated on the flow chart under Fig. 4.

3.3.1.1 Threshing (removal of fruit from the bunches)

The fresh fruit bunch consists of fruit embedded in spikelets growing on a main stem. Manual threshing is achieved by cutting the fruit-laden spikelets from the bunch stem with an axe or machete and separating the fruit from the spikelets by hand.

3.3.1.2 Sterilization of bunches

Sterilization is a means of using high temperature wetheat treatment of loose fruit by pressurized steam. It is critical for the final oil quality and strippability of the fruits. Sterilization inactivates lipolytic enzymes in the fruit mesocarp and prevents buildup of free fatty acids $(\mathrm{FFA})^{9)}$. In addition, it also softens the fruit mesocarp for digestion, facilitates release of oil, and conditions nuts to minimize kernel breakage. Moreover, gums and resins in the oil can cause foaming of oil during frying, here of hot water treatment of the palm seed hydrolyzes gums, resins, starch and coagulates proteins ${ }^{21)}$.

\subsubsection{Digestion of the fruit}

Digestion is the process of releasing the palm oil in the fruit through rupturing or breaking of the oil-bearing cells. The digester commonly used consists of a steam-heated cylindrical vessel fitted with a central rotating shaft carrying a number of beater (stirring) arms. Through the action of the rotating beater arms the fruit is pounded. Digesting the fruit at high temperature, helps to reduce the viscosity of the oil, destroys the fruits' outer covering (exocarp), and completes the disruption of the oil cells already begun in the sterilization phase ${ }^{22)}$.

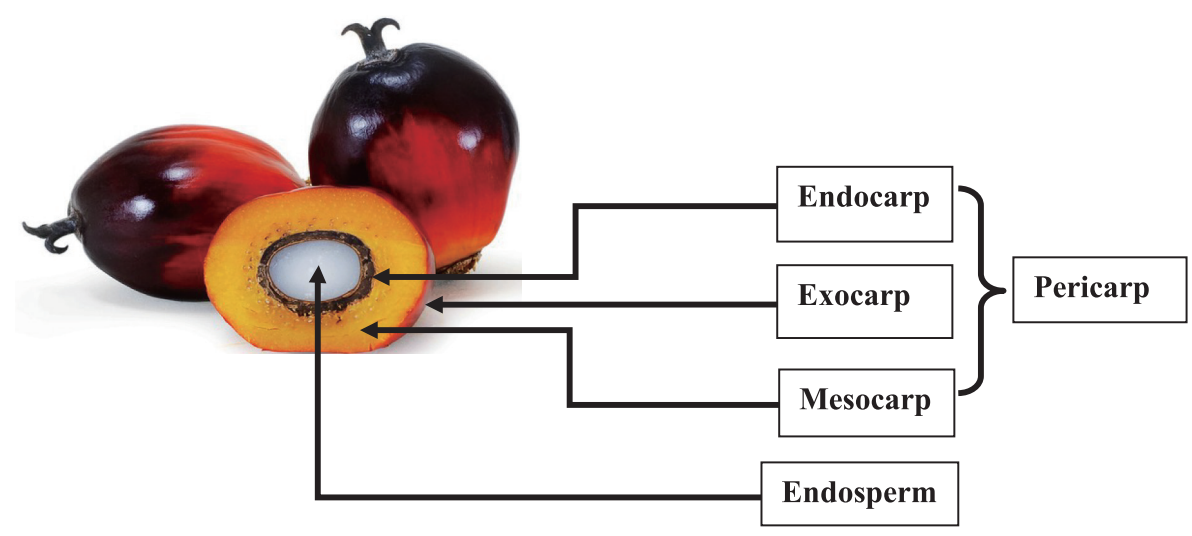

Fig. 3 Cross section of palm fruit. 


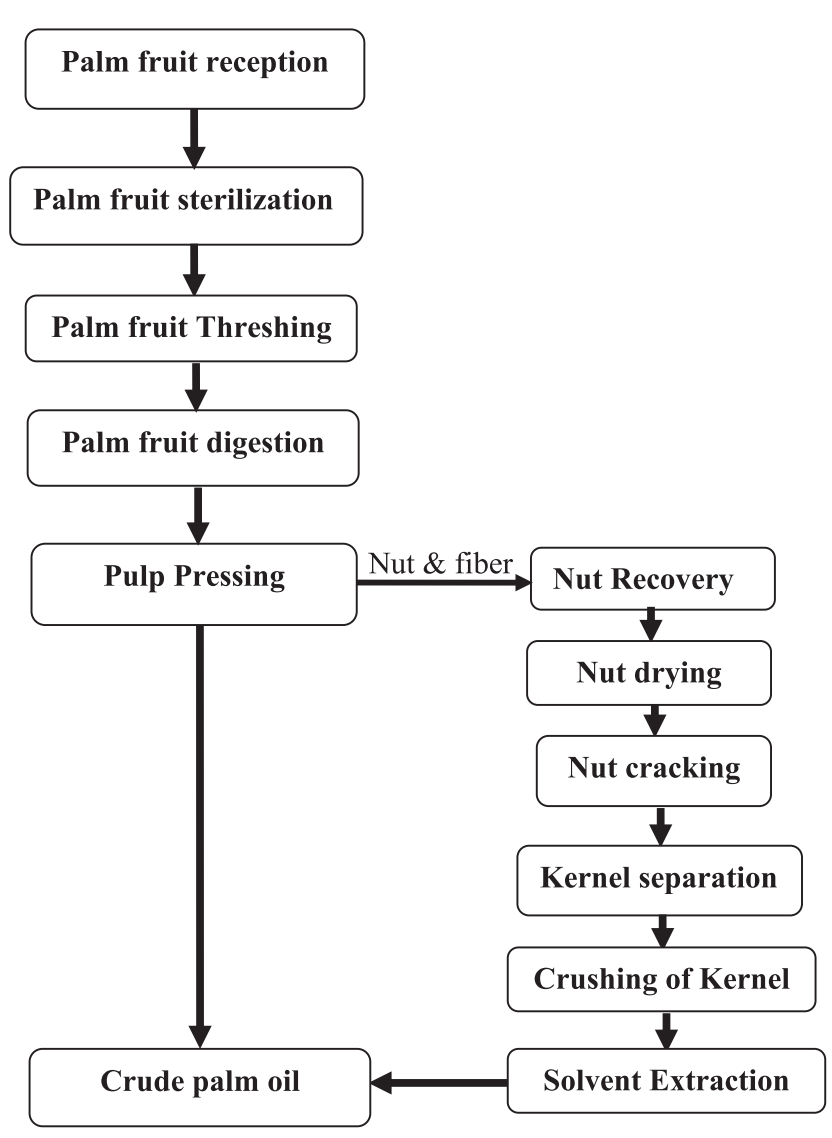

Fig. 4 Crude palm oil processing flow chart.

\subsubsection{Pulp pressing (Extracting the palm oil)}

There are two distinct methods of extracting oil from the digested material. One system uses mechanical presses and is called the 'dry' method. The other called as 'wet' method uses hot water to leach out the oil. In the 'dry' method extraction achieved by squeezing the oil out of a mixture of oil, moisture, fiber and nuts by applying mechanical pressure on the digested mash. Presser may be designed for batch (small amounts of material operated upon for a time period) or continuous operations. After pressing the nut separated and collected for further extraction oil from the kernel and extracted crude palm oil will subjected for refining process to improve color and flavor by removing products of hydrolysis and oxidation. Furthermore, the oil can be fractionated to solid and liquid phase by controlled cooling, crystallization and filtering through thermo mechanical means. The liquid fraction(olein) is used for cooking purpose ${ }^{9)}$.

3.3.2 Extraction oil from palm kernel(Endosperm)

Extraction of oil from the palm kernels is generally differing from palm flesh oil extraction. Likewise extraction oil from other oilseed it requires milling of the kernel. The stages in this process comprise grinding the kernels into small particles, heating (cooking), and the oil finally extracted by using extraction solvent such as petroleum ether and ethyl ether.

3.3.2.1 Refining of crude palm oil

Crude oil contains several impurities that have adverse health consequences. So that, the objective of refining is to remove those unnecessary impurities such as gums, cell debris, fibrous materials, non-oily solids, free fatty acids, metals, pigments, residual soap, phospholipids, volatile oxidation products and other contaminants ${ }^{23)}$. One of the major constraints of vegetable oil refining process is the formation of process induced contaminants. Namely, 2-monochloropropane-1,3-diol fatty acid esters (2MCPDE), 3-monochloropropane-1,2-diol fatty acid esters (3-MCPDE), and glycidol fatty acid esters $(\mathrm{GE})^{24)}$. They commonly occur in higher concentration in palm oil than other vegetable oils ${ }^{25,26)}$. The toxicants known to pose in having of several clinical endpoints such as antifertility, nephrotoxic, in vitro genotocity and particularly, 3-MCPDE is proven carcinogen in animals and might alter normal functioning of different organs ${ }^{27)}$. Furthermore, the contaminants are classified as possibly carcinogenic to human by International Agency for Research on Cancer $(\text { IARC })^{28)}$. Consequently, European Food Safety Authority (EFSA) established maximum tolerable daily intake limit for $3-\mathrm{MCPDE}$ as $2 \mu \mathrm{g} / \mathrm{kg}$ per body weight and joint expert committee of FAO/WHO expert committee on food additives and contaminants (JECFA) set $4 \mu \mathrm{g} / \mathrm{kg}^{29)}$.

These toxicants formed in the oil during refining process and various factors attributed for their formation in the oil. Mainly treating the oil at high temperature during bleaching, degumming and deodorization steps identified as the main reason behind their development ${ }^{24,30)}$. Furthermore, quality of the crude oil, enzymatic hydrolysis of acylglycerols during harvesting and processing are also indicated as causative agent for the formation in of 2-, 3-MCPDE and $\mathrm{GE}^{31)}$. In addition, Šmidrkal et $a l^{32)}$ reported high free fatty acid(FFA) content of the oil also result in having of higher level of 3-MCPDE.

In the last decade, efforts made by different researchers to find appropriate mitigation strategy to reduce the level of these toxicants formation during refining of oil and they are not fully effective. Early work by Ramli et $a l .{ }^{33)}$, used different degumming, bleaching and deodorizing parameters and the level of 3-MCPDE reduced by 64\%. Recently, Hew et $a l{ }^{34)}$, reported the effectiveness of using optimal dose of different leaching earth in reducing 3-MCPDE and $\mathrm{GE}^{34)}$. Strong centrifugation and clay washing are also suggested as an effective means of lowering level of MCPDE content of refine oil ${ }^{35)}$. More recently, Oey et $a l .{ }^{24)}$ achieved $87 \%$ reduction in GE by using double refining with highlow deodorization temperature. So far no effective mitigation strategy reported for 2-MCPDE ${ }^{24)}$. To make the oil suitable for human consumption, the oils must be purified. Final product should have light color; bland taste and stability over oxidation are required. To achieve this, the oil 


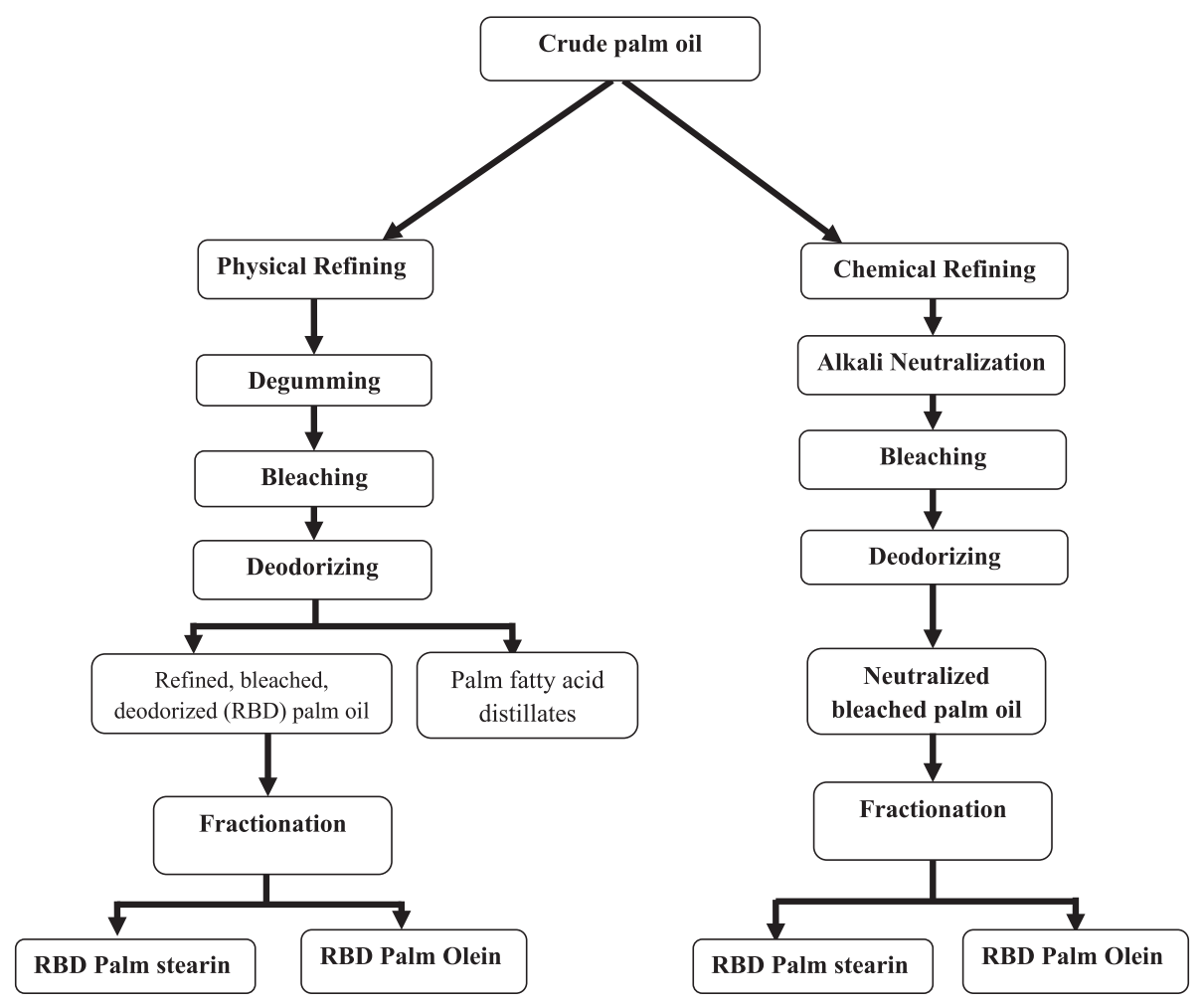

Fig. 5 Crude oil refining process flow chart ${ }^{9)}$.

subjected to several treatments ${ }^{36)}$. Figure 5 above depicts crude oil refining process flow chart and detail process described below.

\subsubsection{Degumming}

Degumming is a process of removing easily hydratable phosphatides [Phosphatidyl choline (PC) and Phosphatidyl inositol(PI) $]$ and metals by mixing the oil with water ${ }^{36)}$. Crude oil can be heated at $90-110^{\circ} \mathrm{C}$ and mixed with phosphoric or citric acid and then retained for 5-20 $\min ^{23,37)}$. The amount of phosphoric acid recommended as 0.05$0.1 \%$ weight of palm oil with $80-85 \%$ concentration $^{37)}$. Followed by mixing the oil with $2-5 \%$ water and undergoes centrifuge separation. Since the phospholipids form insoluble hydrate while they are in contact with water it makes the separation straightforward ${ }^{23)}$.

\subsubsection{Bleaching}

It is removing of coloring pigments and decomposition of hydroperoxides from the oil. Removal of impurities from the oil can be attained by the principle of adsorption mechanism $^{36)}$. In palm oil bleaching different coloring pigments such as caretenoids are adsorbed physically from the soil by the help of neutral acid activated clay minerals via 'Van der Waals' surface attraction forces. But, other impurities chemically bounded by covalent or ionic bonds ${ }^{23)}$. In physical refining bleaching requires heating of the palm oil at $100^{\circ} \mathrm{C}$ and treated with bleaching earth solution in the range of $0.5-20 \%$ weight of the palm oil ${ }^{37)}$.

\subsubsection{Neutralization}

The main objective of neutralization is removing free fatty acids by saponification and neutralizes phosphoric acids added in the degumming steps. In neutralization step caustic soda, potassium hydroxide or excess amount of sodium hydroxide solution, followed by washing out of soaps and hydrated phospholipids ${ }^{23)}$.

\subsubsection{Deodorization}

Deodorizing is a way of removing volatile components, mainly aldehydes and ketones, with low threshold values for detection by taste or smell. Deodorization is essentially a steam distillation process carried out at low pressures (2-6 mbar) or under vacuum (2-4 $\mathrm{mmHg}$ ) and at elevated temperatures $\left(240-260^{\circ} \mathrm{C}\right)^{9,37)}$.

\subsubsection{Fractionation of palm oil}

Fractionation is a process of separating mixtures into two or more fractions based on their physical and chemical properties. It includes redistribution of fatty acids chain through crystallization and filtration to reduce the degree of unsaturation of the acyl group. Separation based on difference in solidification, solubility or volatility of the constituents ${ }^{9)}$. Moreover, fractionation process removes other undesirable content of the oil. As a result of high saturated fat content, palm oil is semi-solid at room temperature. By fractionation liquid and solid fraction of palm oil is obtained. The liquid fraction is known as palm olein and solid fraction is called as palm stearin that obtained without any modification process ${ }^{38)}$. Palm stearin is used in the food in- 
dustry in bread, cake-like pastry, margarine and shortening production $^{39)}$. Liquid fraction of palm oil that is clear and colorless at room temperature and it is safe for human cooking and to use as edible cooking oil ${ }^{9)}$. Palm super olein is produced by further fractionating palm olein, and the oleic and linoleic fatty acid content in this oil is higher than that in palm olein. Palm top olein is produced by further fractionating palm super olein. As the fractionation procedures precede, the iodine value of the oil increases ${ }^{14)}$.

\subsection{Quality parameter for palm oil}

According to Codex Alimentarius, palm oil should be free from any objectionable matter, any substance from microbial source and other toxic substances like heavy metals, pesticide residues in the concentration that affect human health. Furthermore, the oil is expected to be free from foreign, rancid odor and taste ${ }^{40)}$. Specific quality parameters for palm oil indicated below on Table 1 .

\subsection{Nutritional value of palm oil}

Palm oil extracted both from the mesocarp and kernel of the fruit contains different amount of saturated fatty acids. More than half of the oil from both the mesocarp and kernel of the seed contain saturated fats ${ }^{11)}$. However, specific compositions of the fatty acids vary in the oil extracted from mesocarp and kernel. Palmitic acid (C16) is the predominant saturated fatty acid in the oil from mesocarp. But, in palm kernel oil the Lauric acid (C12) is found in highest concentration ${ }^{41)}$. As indicated below on Table 2 palm oil from the fruit and kernel of palm seed contains significant amount of unsaturated fatty acids ${ }^{2,11)}$.

In addition to fatty acids, palm oil contains several phytochemicals like vitamin $\mathrm{E}$ (both in the form of tocotrienols and tocopherols), ubiquinone (coenzymes Q10) naturally occurring coenzyme that has superior antioxidant property than vitamin E, phytosterols, carotenes, squalene, polyphenols and phospholipids ${ }^{8,9,42}$. The concentration of different phytochemicals in palm oil indicated below on Table 3.

\subsection{Palm oil import of Ethiopia}

Ethiopia is one of center of origin for various oilseeds and produces 784,890 tons of oilseeds per year and consumes 8.9 liter cooking oil on average annually ${ }^{43)}$. Total edible oil consumption for 2020/21 fiscal year projected around 630,000 MT and majority of the edible oil demand satisfied from import and so far $90 \%$ of the amount required for 2020/21 is imported. The highest share of imported edible oil is palm oil. In 2020/21 the highest amount $47.5 \%$ of the total palm oil import is from Indonesia valued \$ 95 million. Secondly, from Malaysia holds $35.5 \%$ of palm oil import share and accounts $\$ 71$ million. Djibouti is the third highest palm import destination for Ethiopia, a palm oil valued \$29 million imported and covers $14.5 \%$ of total palm oil import share ${ }^{44)}$. According to Addis Fortune report, the government acknowledged 23 private and stateowned companies to import refined palm oil and planned

Table 1 Quality parameters of palm oil ${ }^{40)}$.

\begin{tabular}{cll}
\hline No. & \multicolumn{1}{c}{ Quality parameter } & \multicolumn{1}{c}{ Recommended value } \\
\hline 1. & Moisture and volatile matter at $105^{\circ} \mathrm{C}$ & $0.2 \%$ maximum $(\mathrm{m} / \mathrm{m})$ \\
2. & Insoluble impurities & $0.05 \%$ maximum $(\mathrm{m} / \mathrm{m})$ \\
3. & Free fatty acid & $0.1 \%$ maximum expressed as Palmitic acid \\
4. & Acid value & $0.6 \mathrm{mg}$ maximum of $\mathrm{KOH} / \mathrm{g}$ oil \\
5. & Color & $5-1 / 4$ inch Lovibond cell \\
& & Red: 3 Maximum \\
& & Yellow: 30 Maximum \\
6. & Soap content & $0.005 \%$ maximum \\
7. & Peroxide value & 2 meq of active oxygen per kg of oil at a time of purchase \\
& & 10 meq per kg of oil throughout shelf life \\
8. & Melting point & $24{ }^{\circ} \mathrm{C}$ \\
9. & Saponification & $194-202$ mg KOH per g oil \\
10. & Unsaponifable matter & $1.3 \%$ maximum \\
11. & Iodine value & $55-60 \mathrm{~g}$ per $100 \mathrm{~g}$ oil \\
12. & Refractive index $\left(\mathrm{ND} 40^{\circ} \mathrm{C}\right)$ & $1.458-1.460$ \\
13. & Relative density $\left(40^{\circ} \mathrm{C} / \mathrm{water}\right.$ at $\left.20^{\circ} \mathrm{C}\right)$ & $0.899-0.920$ \\
14. & Vitamin A & $240000-36000 \mathrm{IU}$ per kg oil \\
15. & Vitamin D & $2400-3600 \mathrm{IU}$ per kg oil \\
\hline
\end{tabular}


Table 2 Saturated and unsaturated fatty acid composition of palm oil and palm kernel oil ${ }^{11}$.

\begin{tabular}{|c|c|c|c|c|}
\hline \multicolumn{5}{|l|}{ Saturated fatty acids } \\
\hline & & & Palm Oil & Palm kernel Oil \\
\hline Caprylic acid (C8) & & $8: 0$ & - & $3.3 \%$ \\
\hline Carpic acid (C10) & & $10: 0$ & - & $3.5 \%$ \\
\hline Lauric acid (C12) & & 12:0 & $0.2 \%$ & $47.8 \%$ \\
\hline Myristic acid (C14) & & $14: 0$ & $1.1 \%$ & $16.3 \%$ \\
\hline Palmitic acid (C16) & & $16: 0$ & $44.0 \%$ & $8.5 \%$ \\
\hline Stearic acid (C18) & & $18: 0$ & $4.5 \%$ & $2.4 \%$ \\
\hline \multicolumn{5}{|l|}{ Unsaturated fatty acids } \\
\hline Monounsaturated fatty acid & Oleic acid (C18) & $18: 1$ & $39.2 \%$ & $15.4 \%$ \\
\hline Polyunsaturated fatty acid & Linoleic acid (C18) & $18: 2$ & $10.1 \%$ & $2.4 \%$ \\
\hline
\end{tabular}

Table 3 Different phytochemicals content of palm oil ${ }^{42}$.

\begin{tabular}{cc}
\hline Components & Concentration \\
\hline Vitamin E (tocotrienols and tocopherols) & $600-1000 \mathrm{ppm}$ \\
Coenzyme Q10 & $10-80 \mathrm{ppm}$ \\
Phytosterols & $300-620 \mathrm{ppm}$ \\
Carotenes & $500-700 \mathrm{ppm}$ \\
Squalene & $250-540 \mathrm{ppm}$ \\
Polyphenols & $40-70 \mathrm{ppm}$ \\
Phospholipids & $10-100 \mathrm{ppm}$ \\
\hline
\end{tabular}

\section{Ethiopian Palm oil import by year}

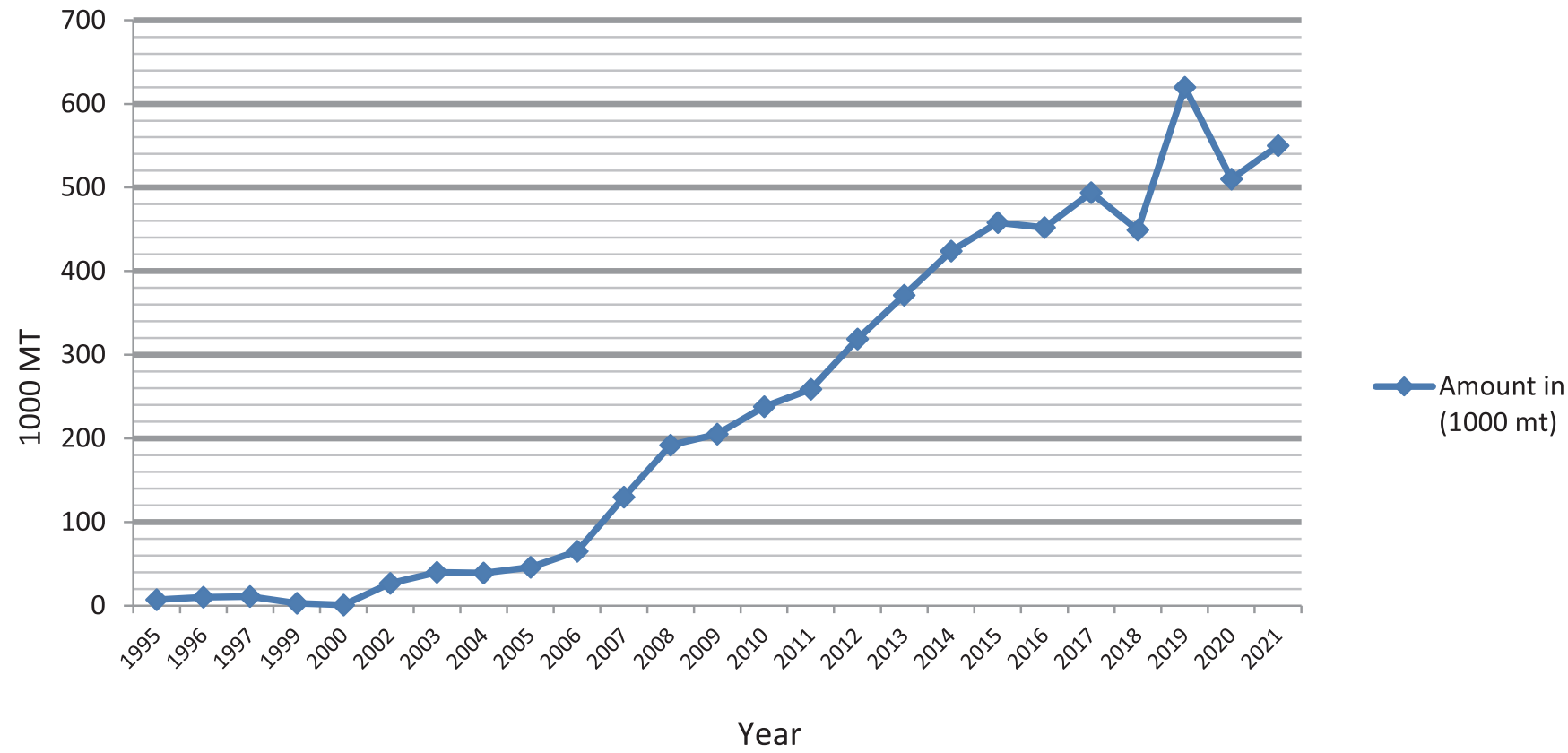

Fig. 6 Ethiopia palm oil import by years ${ }^{45)}$. 
to import 2 million litres per month ${ }^{43}$. Moreover, recently in 21 February, 2020 largest edible refining factory called Phibella with a capacity of producing 1500 MT palm oil per day and expected to satisfy $60 \%$ edible oil demand of the country inaugurated ${ }^{44}$. As indicated above on Fig. 6, the amount of imported palm oil upsurges from time to time. In 1995, the country imported 7 thousand MT palm oil and as a result of increased demand in 2021, 550 thousand MT palm oil imported ${ }^{45)}$.

\subsection{Health benefits of palm oil}

The dominant saturated fat of palm oil is palmitic acid a 16 carbon chain is one of the essential fatty acids in cell membrane, transportation, secretary lipids and part of human body. Besides, palmitic acid is also involved in energy production like ability to join certain proteins required for the normal functioning of nervous system and formation of binding between cells ${ }^{2,46,47)}$. Moreover, antioxidant content of palm oil in the form of tocopherols and tocotrienols provides protective effect for cells and tissues from against oxidative stress as a result of free radicals. Vitamin $\mathrm{E}$ content of palm oil is also protective over cellular ageing, cancer, artheriosceleriosis, and arthritis and Alzheimer disease. Furthermore, tocotrienols in palm oil lowers blood low density lipoprotein cholesterol (LDL-C) level by $7-38 \%$ without compromising the level of good cholesterol, high density lipoprotein (HDL) through inhibition of the activity of the enzyme that regulates cholesterol synthesis in liver called HMG Coa reductase $(\text { HMG R })^{1,6,48)}$.

\subsection{Palm oil consumption and associated health effects}

Controversies over consumption of palm oil rose due to its high saturated fat composition. According to Expert consultation on fats and fatty acids in human nutrition report in 2010, there is potential evidence that total cholesterol(TC) and low density lipoprotein cholesterol (LDL-C) effect of palmitic acid from vegetable source is lower than palmitic acid from animal source fat. In palm oil, as indicated below on Fig. 7 steriospecific number $s n-1$ and $s n-3$ position of the triglyceride occupied with palmitic acid (saturated fatty acid) and the remaining $s n-2$ position occupied by oleic acid (C18:1) or linoleic acid (C18:2) (unsaturated fatty acid) like that of olive oil, these property makes palm oil more bioavailable ${ }^{1)}$. Consequently, even palm oil contain $50 \%$ saturated fatty acids it is liquid at room temperature and it perform as monounsaturated fat. Palm triglyceride contains 7-11\% saturated fatty acid (palmitic acid (C16:0) or stearic acid (C18:0) ) and 87\% unsaturated fatty acid (oleic acid (18:1) or linoleic acid (18:2)) in sn-2 position. However, in animal fats like lard, human milk and cow milk $70 \%, 53-70 \%$ and $38 \%$ of $s n-2$ position of the triglyceride is occupied by palmitic acid, respectively. As a result of steriospecific number (sn) position of triglycerides of palm oil does not have cardiovascular risk ${ }^{42)}$.

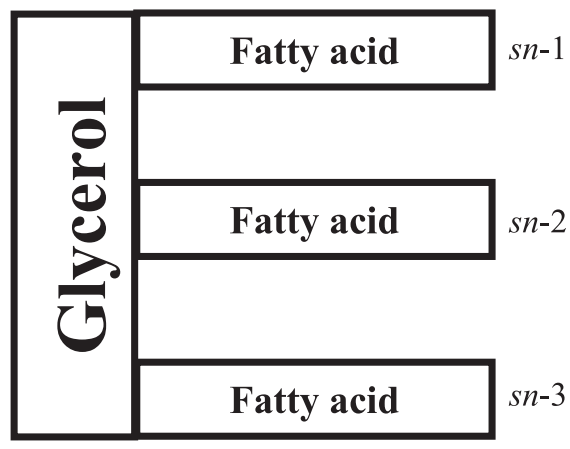

Fig. 7 Triglyceride structure with steriospecific numbering.

Different in vitro and in vivo studies conducted by various researchers regarding palm oil saturated fat effect on blood cholesterol and other non communicable diseases and some of these findings indicate negative health effects of consuming palm and others advocate positive health benefits of palm oil. Early comparative study from human experimentation by Tholstrup et $a l .{ }^{49)}$ depicts that palm olein relatively increased plasma TC and LDL-C level $(p<$ 0.0001) as compared to olive oil ${ }^{49)}$. Also, in subsequent year, Xian et $a{ }^{50}{ }^{50}$ conducted a research on the effect of reheated palm oil consumption as a risk factor for arteriosclerosis. They concluded using of repeatedly heated palm oil is becoming a predisposing factor of arthrosclerosis and leading to cardiovascular disease ${ }^{50)}$. A work by Fattore et $a l .{ }^{51)}$ stated consumption of oil that has $50 \%$ and above saturated fat increases blood cholesterol and has risk of coronary heart disease and obesity ${ }^{51)}$.

Oppositely, in vivo study carried out by Go et $a l .{ }^{52)}$ to assess the effect of palm and sun flower oils on serum cholesterol and fatty liver of rats. Sprague-Dawley (SD) rats used for the experimentation and $2.5 \mathrm{~mL}$ of experimental diet orally administered for 22 days and no significance difference on serum lipid level recorded ${ }^{52}$. Likewise, randomized trial conducted to see the effect of hybrid palm oil supplement on human plasma lipid pattern. One hundred sixty participants randomly grouped into two groups and subjected to two different treatments $(25 \mathrm{~mL}$ hybrid palm oil and $25 \mathrm{~mL}$ extra virgin olive oil) per day for 90 days. The researchers found no significant difference on $\operatorname{TC}(p=$ $0.0525)$, LDL-C $(p=0.2356)$, HDL-C $(p=0.8293)$ and TAGs $(p=0.3749)$ on participants between both treatment groups. Moreover, hybrid palm oil consumption showed similar effect on plasma lipid to extra virgin olive oil ${ }^{53)}$.

A randomized double blind cross over trial study conducted in China on the effect of palm olein and olive oil on serum lipid by Sun et $a l{ }^{54)}$. The study conducted on 120 participants by providing each of them with $48 \mathrm{~g}$ test oil per day for two consecutive months. The palm olein and olive oil showed statistically insignificant $(p>0.05)$ effect on serum TC, LDL-C and HDL-C level of study partici- 
pants $^{54)}$. More recently, a randomized in vivo control trail by Baer et $a l{ }^{55)}$, found that palm oil and palm kernel oil significantly increased HDL-C $(p<0.001)$ as compared to high-oleic soybean oil and fully hydrogenated soybean oil $^{55)}$. In agreement to these findings, a systematic review by Ismail $e t a l .{ }^{13)}$ indicated that evidences from available

Table 4 Summary of studies on palm oil and associated health effects.

\begin{tabular}{|c|c|c|}
\hline Study & Objective & Method \\
\hline $\begin{array}{l}\text { Palm olein increases } \\
\text { plasma cholesterol } \\
\text { moderately compared } \\
\text { with olive oil in } \\
\text { healthy individuals }\end{array}$ & $\begin{array}{l}\text { To investigate the } \\
\text { effect of diet rich } \\
\text { in palm olein, } \\
\text { fractionated palm } \\
\text { oil, olive oil and lard } \\
\text { on plasma blood } \\
\text { lipid, inflammatory } \\
\text { markers, glucose and } \\
\text { insulin }\end{array}$ & $\begin{array}{l}\text { Controlled double blinded, } \\
\text { randomized } 3 \times 3 \text { wk crossover } \\
\text { dietary intervention study on } 32 \\
\text { healthy men individuals who } \\
\text { replaced their habitual dietary } \\
\text { fat intake with } \sim 17 \% \text { of energy } \\
\text { from palm olein, olive oil or lard, } \\
\text { respectively }\end{array}$ \\
\hline
\end{tabular}

Effect of palm oil and sunflower oil on serum cholesterol and fatty liver in rats

Palm oil and Cardiovascular disease: A randomized trial of the effects of hybrid palm oil supplement on human plasma lipid pattern

Oil palm Phenolics (OPP) inhibit Pancreatic cancer cell proliferation via suppression of NF-kB pathway

Selective anti-cancer effects of palm phytonutrients on human breast cancer cells

Consumption of High-Oleic soybean oil improves lipid and lipoprotein profiles in Humans compared to palm oil blend: A randomized control trial
To examine the effect of palm oil and sunflower oil on serum cholesterol and fatty liver of rats

To assess the effect of hybrid palm oil supplement on human plasma lipid pattern.

To investigate the effect of palm oil phenolics (palm juice) on pancreatic cancer cells

To compare anticancer effect of palm tocotrienols, carotenoids, squalene and Coenzyme Q10.

To determine how consumption of diets containing high-oleic soybean oils compared to other alternative oils, with similar functional properties modifies LDL-C and other risk factors and biomarkers of coronary heart disease
Healthy SD male rates grouped into four groups, each group with 5 rats as control group, 2.5 $\mathrm{mL}$ palm oil/day treated, $2.5 \mathrm{~mL}$ sunflower treated and $2.5 \mathrm{~mL}$ palm and sunflower oil combination treated groups for 22 days

One hundred sixty $(\mathrm{n}=160)$ study participants randomized and assigned to one of the two treatment groups $(25 \mathrm{~mL}$ hybrid palm oil (HPO) or $25 \mathrm{~mL}$ extra virgin olive oil (EVOO)) for 3 months

Two pancreatic cancer cell lines (PANC-1 and BxPC-3) treated with different dose $(20,30,40$ and $50 \mu \mathrm{L})$ oil palm phenolics ( 1500 $\mathrm{mg} / \mathrm{mL} \mathrm{GE}$ ) per $\mathrm{mL}$ of cell culture for $72 \mathrm{hrs}$.

Two breast cancer cell lines (Highly aggressive triple negative MDA-MB-231 and estrogen dependent MCF-7) treated with palm phytonutrients.

A triple blind, crossover, randomized controlled trial on human subjects conducted with four treatment groups, 1). High-oleic soya bean $(n=48)$, 2). 80:20 blend of HOSBO and fully hydrogenated soybean oil (FHSBO) $(n=50), 3)$. Soybean oil (SBO) $(n=50)$, and 4). 50:50 blend of palm oil (PO) and palm kernel oil $(\mathrm{PKO})(\mathrm{n}=49)$ for 29 days.
Overall reduction in TC $(7.4 \%, p<$ $0.001)$ and LDL-C (15.6, $p<0.0001)$ recorded. No significant difference observed between both treatment groups in repeated measurement analysis of variance for TC $(p=0.0525)$, LDL-C $(p=0.2356)$, HDL-C $(p=0.8293)$ and TAGs $(p=0.3749)$

PANC-1 cell line treated with at 20 , 30, 40 and $50 \mu \mathrm{L}$ oil palm inhibited cell growth by $35 \%, 51 \%, 75 \%$ and $91 \%$, respectively. In case BxPC-3 cell line also $12 \%, 30 \%, 54 \%$ and $75 \%$ cell growth inhibition recorded. Palm oil phenolics suppressed pancreatic cancer cell growth in dose dependant manner.

From the palm phytonutrients tocotrienols exhibited superior ability to induce human breast cancer cell death by apoptosis as compared to other phytonutrients.

LDL-C, apolipoprotein B (apoB), non HDL-C ratios of TC-to-HDL-C and LDL-C-to-HDL-C and LDL particles number and small LDL particles concentration were lower after HOSBO and $\mathrm{HOSBO}+\mathrm{FHSBO}$ compared to $\mathrm{PO}(p<0.05)$. $\mathrm{PO}+\mathrm{PKO}$ increased HDL-C $(p<0.001)$ and apoprotein$\mathrm{AI}(p<0.03)$ compared to HOSBO and HOSBO+FHSBO. The dietary treatment did not affected CHD markers.
Lucci et $a l .{ }^{53)}$

Gupta et $a .^{56)}$

Loganathan et al. $^{57)}$

Baer et al. ${ }^{55)}$ .
Tholstrup et

$a l .{ }^{49)}$

Go et $a l .{ }^{52)}$ 
study findings are not sufficient enough to conclude palm oil consumption as a causative agent for cardiovascular disease $^{13)}$. In fact, majority of cholesterol in our body synthesized by the body itself and small amount obtained from diet, especially animal fats like butter but it is lacking in vegetable oils including palm oil ${ }^{1)}$.

In another way palm oil phytochemicals identified to have anti cancer effect. A study conducted to assess the effect of palm oil phenolics on pancreatic cancer cell, the palm oil phenolics effectively suppressed pancreatic cancer cell in dose dependent manner ${ }^{56)}$. Likewise, a work by Loganathan $e t a l .{ }^{57}$ identified the suppression anti breast cancer effect of tocotrienols from palm plant. Tocotrienols induced cell death of human breast cancer cells through apoptosis $^{57}$. Table 4 above indicates summary of studies on palm oil and associated health effects.

\section{Discussion}

Vitamin A deficiency is one of public health problem in Ethiopia and other parts of the world. Available scientific findings indicate that palm olein has the ability to alleviate vitamin A deficiency. Beta carotene content of the oil has significant effect in combating such public health concern. For instance, a controlled randomized study conducted in South Africa on 265 school children aged 5-11 years for six months by Van Stuijvenberg et al. ${ }^{58)}$ point out that red palm oil fortified biscuit brought significant $(p<0.005)$ effect on their serum retinol level ${ }^{58)}$. In addition, literature reviewed by Loganathan et $a l .{ }^{59)}$ revised several literatures on the health promoting effect of red palm oil from human and animal experimentations and depicted that palm oil beta carotene content as a good means of overcoming vitamin A deficiency in children, mothers and adults ${ }^{59)}$. So, it is better to consider using of palm oil to address such public health problems.

In Ethiopia, road side fast foods such as chips become a common trend in great Addis and other regional cities. Fast food processers use palm oil for frying purpose and they use the oil again and again, under such condition the oil chemistry will be changed and it becomes problematic for health. Repeatedly heated palm oil is also indicated as a risk factor for arteriosclerosis and leading to cardiovascular disease by Xian et $a l .{ }^{50)}$. So that, further investigation of the health effect of repeatedly heated palm oil is recommended, in addition selecting appropriate oil type for a specific type of processing is necessary.

Literatures suggest palm olein (liquid fraction of palm oil) for food consumption and palm stearin (solid fraction of palm oil)for other purposes like bread, cake-like pastry, margarine and shortening production ${ }^{39)}$. Besides palm kernel oil is recommended for non food purpose and used in cosmetics industry. However, the palm oil imported to
Table 5 Nutritional information of a palm oil imported to Ethiopia.

\begin{tabular}{lr}
\hline \multicolumn{1}{c}{ Nutritional information } & Content \\
\hline Saturated fat & $41.7 \mathrm{~g}$ \\
Monounsaturated fatty acid & $38.7 \mathrm{~g}$ \\
Polyunsaturated fatty acid & $9.3 \mathrm{~g}$ \\
\hline
\end{tabular}

Ethiopia in 20 Liter is semi solid and it is used for cooking purpose and the semi solid version of the oil is not safe for consumers. This idea further strengthened by a study finding by researchers group from Ethiopian Public Health institute on safety and nutritional quality of commercial edible oils in Addis Ababa, identified significant $(p<0.05)$ amount of trans, saturated, monounsaturated fatty acid, omega 6 and cis fats in imported palm oil. The researchers concluded that saturated fatty acid content of the palm oil is above WHO daily recommended amount ${ }^{18)}$. So that, Ethiopia Food Medicine and Health Care Authority and other regulatory bodies should properly inspect imported palm oil compliance with its nutritional labeling, here above on Table 5 nutritional labeling of one of the palm oil brands imported to Ethiopia is indicated but the oil tends to be solid at room temperature. In selection of cooking oil consumers should focus on types of the fatty acid in the oil as saturated fatty acid, monounsaturated fatty acid and polyunsaturated content of the oil and trans fatty acids that formed by hydrogenation process are not recommended and healthy.

\section{Challenges and Prospects}

In 2020/21, 83.96 million MT palm oil and palm kernel oil is consumed and covers the highest share of edible oil consumption in the fiscal year ${ }^{5}$. It remains the most traded and consumed vegetable oil. Therefore, it is believed to offer a significant economic benefits for various stakeholders engaged. However, there are certainly undeniable concerns that pose a challenge on the sustainable production and consumption of palm oil in the global market. An increased use of oil palm for oil production is often condemned due to its adverse effect on the environment by intensifying deforestation, carbon emission into the atmosphere, displacing indigenous peoples, endangerment of species toward extinction, loss of biodiversity and consequently climate change ${ }^{60-62}$. The other concern is formation of 2-monochloropropane-1,3-diol fatty acid esters (2MCPDE), 3-monochloropropane-1,2-diol fatty acid esters (3-MCPDE), and glycidol fatty acid esters (GE) contaminants. These crude oil refining step induced toxicant occurrence in palm oil in higher extent than other vegetable oils is a challenge and no appropriate mitigation strategy 
developed yet.

Despite aforementioned doubtful issues with a sustainable production and utilization of palm, it contributes significantly to the global supply of edible oils. It is entirely GMO-free and the highest-yielding vegetable oil crop (produces up to 10 times more oil) per unit area than other oilseed crops. Oil palms are considerably more efficient than other oil-producing crops. It needs less than half the land required by other crops (such as sunflower, soybean or rapeseed) to produce the same amount of oil. This makes palm oil the least expensive vegetable oil in the world. In addition, the oil has high economic benefit and the palm oil industry has helped lift millions of people out of poverty in some countries like Indonesia and Malaysia ${ }^{63)}$. Palm oil has a long shelf life and is solid at room temperature, making it an ideal ingredient in a wide variety of food applications. Furthermore, palm oil has unique benefits due to the content of its functional components, such as tocopherol, tocotrienols and carotene ${ }^{63)}$ and specific fatty acids and palmitic acid which are identified to involve in regulation of tumor growth ${ }^{11)}$.

Even though, palm oil is the measure edible oil consumed in Ethiopia, oil palm plantation and production are at their infancy stage and not practiced extensively. Consequently, state investment agency published a document in 2012 that invite investors who want to take part on oil palm plantation and palm oil production and refining process. As indicated on the document various investment opportunities described such as identified potential areas that fit for oil palm plantation, market opportunities for producers, labor, investment incentives by the government, customs duty exemption, income tax exemption, loss carry over forward, remittance of funds, investment guarantee and protection, reduced land cost and utilities. Moreover, national edible oil demand and supply did not meet yet. So, investing on oil palm and palm oil processing is a good opportunity for investors.

\section{Conclusion}

Palm oil extraction process, refining and health consequences of palm oil have been addressed in the present review. Palm oil is extracted both from fruit and seed of palm tree and it is the world's most commonly used vegetable oil. However, its high saturated fatty acid content raised controversies over consumption of the oil. Few scientific findings suggest it as a risk factor for cardiovascular disease and increased consumer's awareness over healthy diet raised claim over it. Various studies from animal and human experimentation suggest the oil does not affect serum cholesterol level. They identified that palmitic acid from plant source has insignificant effect in raising blood total cholesterol and low density lipoprotein cholesterol level as compared to palmitic acid from animal source. In converse, tocotrienols in the oil are known to reduce serum LDL level by $7-38 \%$ without compromising the level of HDL. Furthermore, articles suggest that arrangement of triglycerides in palm oil does not have a cardiovascular risk and evidences from available studies are not sufficient enough to conclude palm oil as a risk factor for cardiovascular disease. In terms of health, palm stearin (liquid fraction) is recommended as good oil to use as edible oil. For healthy diet, consumers should focus on the physical state of the oil, source of the oil and type of fatty acids. Finally, regulatory bodies in Ethiopia should properly test imported palm oil complement with their nutritional labeling at their point of entry and cross check quality of palm oil critically. Further studies recommended on mitigation strategies to minimize process induced toxicants of palm oil to acceptable level.

\section{Conflict of Interest}

The authors did not declare conflict of interest.

\section{References}

1) Absalome, M.A.; Massara, C.-C.; Alexandre, A.A.; Gervais, K.; Chantal, G.G.-A. et al. Biochemical properties, nutritional values, health benefits and sustainability of palm oil. Biochimie 178, 81-95(2020).

2) Gesteiro, E.; Guijarro, L.; Sanchez-Muniz, F.J.; VidalCarou, C.M.; Troncoso, A. et al. Palm oil on the edge: Review. Nutrients 11, 2008 (2019).

3) Sheil, D.; Casson, A.; Meijaard, E.; van Nordwijk, M.: Gaskell, J. et al. The impacts and opportunities of oil palm in Southeast Asia: What do we know and what do we need to know? Occasional paper no. 51. CIFOR, Bogor, Indonesia (2009).

4) Ismail, M.A.; Alsalahi, M.U.; Imam, D.J.; Ooi, H.; Khaza'ai, M.A. et al. Safety and neuroprotective efficacy of palm oil and tocotrienol-rich fraction from palm oil: A systematic review. Nutrients 12, 521 (2020).

5) Statista. Consumption of vegetable oils worldwide from 2017/18 to 2019/2020, by oil type (in million metric tons) (2021). Available at https:/www.statista.com/ statistics/263937/vegetable-oils-global-consumption/

6) Mohamed, F.R. Fruit oils: Chemistry and functionality. Springer Nature, Switzerland (2019).

7) GAIN (Global Agriculture Information Network) and USDA (United States Department of Agriculture)Foreign Agricultural Service. Ethiopia Oilseeds Report Annual (2020).

8) Souganidis, E.; Laillou, A.; Leyvraz, M.; Moench-Pfanner, R. A comparison of retinyl palmitate and red palm 
oil $\beta$-carotene as strategies to address Vitamin A deficiency. Nutrients 15, 3257-3271(2013).

9) Mba, O.I.; Dumont, M.J.; Ngadi, M. Palm oil: Processing, characterization and utilization in the food industry. A review. Food Biosci. 10, 26-41 (2015).

10) Daud, Z.A.M.; Kaur, D.; Khosla, P. in Health and nutritional properties of palm oil and its components. A301 Ch18, pp. 545-560 (2012).

11) Mancini, A.; Imperlini, E.; Nigro, E.; Montagnese, C.; Daniele, A.; Orrú, S.; Buono, P. Biological and nutritional properties of palm oil and palmitic acid: Effects on health. Molecules 20, 17339-17361 (2015).

12) Oyewole, O.E.; Amosu, A.M. Public health nutrition concerns on consumption of red palm-oil (RPO): The scientific facts from literature. African Journal of Medical Science 39, 255-262 (2010).

13) Ismail, S.R.; Maarof, S.K.; Siedar Ali, S.; Ali, A. Systematic review of palm oil consumption and the risk of cardiovascular disease. PLOS ONE 13, e0193533 (2018).

14) Yılmaz, B.; Ağagündüz, D. Fractionated palm oils: Emerging roles in the food industry and possible cardiovascular effects. Crit. Rev. Food Sci. Nutr. 1869694 (2021).

15) Sowmya, K.; Robert, M.; Richard, S. The palm oil industry and non communicable diseases. Bull. World Health Organ. 97, 118-128(2019).

16) WHO (World Health Organization). Replace Trans-Fat. WHO/NMH/NHD/18.4,(2018). Available online: https:// www.who.int/nutrition/topics/replace-transfat

17) Ali, S.; Misganaw, A.; Worku, A.; Destaw, Z.; Negash, L. et al. The burden of cardiovascular diseases in Ethiopia from 1990 to 2017: Evidence from the global burden of disease study. Int. Health 13, 318-326 (2020).

18) Kifle, H.; Aweke, K.; Masresha, T.; Kirubel, T.; Tesfaye, H. Safety and nutritional quality of commonly consumed commercial edible oils in Addis Ababa. Ethiopian Journal of Public Health Nnutrition 1(2), 72-77(2020).

19) Teuku Meurah, I.M.; Norasyiqin, I.; Nazia, H.; Arridina, S.S.; Abd Halim, S. Palm oil and its wastes as bioenergy sources: a comprehensive review. Environ. Sci. Pollut. Res. 26, 14849-14866 (2019).

20) Oguntibeju, O.O.; Akinola, F.F.; Adisa, A.W.; Owojuyigbe, O.S. Physico-chemical properties of palm oil from different palm oil local factories in Nigeria. J. Food Agric. Environ. 8, 264-269 (2010).

21) Obibuzor, J.U.; Okogbenin, E.A.; Abigor, R.D. Oil recovery from palm fruits and palm kernel. in Palm oil: Production, processing, characterization and uses (Lai, O.-M.; Tan, C.-P.; Akoh, C.C. eds.). AOCS Press, Urbana, Illinois, USA, pp. 299-328(2012).

22) Azam, A.; Prashad, K.K.; Onn, C.C.; Shaliza, I. A study of palm oil mill processing and environmental assess- ment of palm oil mill effluent treatment. Environ. Eng. Res. 25, 212-221 (2020).

23) Aparicio, R.; Harwood, J. Handbook of olive oil: Analysis and properties. Springer, Boston, MA (2013).

24) Oey, S.B.; van der Fels-Klerx, H.J.; Fogliano, V.; van Leeuwen, S.P.J. Effective physical refining for the mitigation of processing contaminants in palm oil at pilot scale. Food Res. Int. 138, 109748 (2020).

25) EFSA (European Food Safety Authority). Risks for human health related to the presence of 3-and 2-monochloropropanediol (MCPD), and their fatty acid esters, and glycidyl fatty acid esters in food. European Food Safety Authority Journal 14, 4426 (2016).

26) Cheng, W.; Liu, G.; Wang, L.; Liu, Z. Glycidyl fatty acid esters in refined edible oils: A review on formation, occurrence, analysis, and elimination methods. Compr. Rev. Food Sci. Food Saf. 16, 263-281 (2017).

27) Gao, B.; Li, Y.; Huang, G.; Yu, L. Fatty acid esters of 3-monochloropropanediol: A review. Annu. Rev. Food Sci. Technol. 10, 259-284 (2019).

28) Arisseto, A.P.; Silva, W.C.; Tivanello, R.G.; Sampaio, K.A.; Vicente, E. Recent advances in toxicity and analytical methods of monochloropropanediols and glycidyl fatty acid esters in foods. Curr. Opin. Food Sci. 24, 36-42 (2018).

29) Cui, X.; Zhang, L.; Zhou, P.; Liu, Z.; Fan, S. et al. Dietary exposure of general Chinese population to fatty acid esters of 3-monochloropropane-1,2-diol (3MCPD) from edible oils and oil-containing foods. Food Addit. Contam. Part A 38, 60-69 (2021).

30) Jiang, L.; Jing, Z.; Yibaina, W.; Yan, S.; Lili, X. et al. Dietary exposure to fatty acid esters of monochloropropanediols and glycidol of 2- to 3-year-old children attending nursery schools from two areas in China using the duplicate-diet collection method. Food Addit. Contam. Part A 38, 70-80 (2021).

31) Matthäus, B.; Pudel, F. Mitigation of 3-MCPD and glycidyl esters within the production chain of vegetable oils especially palm oil. Lipid Tech. 25(7), 151-155 (2013).

32） Šmidrkal, J.; Tesařová, M.; Hrádková, I.; Berčíková, M.; Adamč́ková, A.; Filip, V. Mechanism of formation of 3-chloropropan-1,2-diol (3-MCPD) esters under conditions of the vegetable oil refining. Food Chem. 211, 124-129, (2016).

33) Ramli, M.R.; Siew, W.L.; Ibrahim, N.A.; Hussein, R.; Kuntom, A. et al. Effects of degumming and bleaching on 3-MCPD esters formation during physical refining. J. Am. Oil Chem. Soc. 88, 1839-1844(2011).

34) Hew, K.S.; Asis, A.J.; Tan, T.B.; Yusoff, M.M.; Lai, O.M. et al. Revising degumming and bleaching processes of palm oil refining for the mitigation of 3 monochloropropane-1,2-diol esters (3-MCPDE) and glycidyl esters 
(GE) contents in refined palm oil. Food Chem. 307, 125545 (2020).

35) Theurillat, X.; Nicolas, M.; Redeuil, K.; Nagy, K. Synergistic effects during physical refining of palm oil to mitigate the formation of monochloropropanediols. Eur. J. Lipid Sci. Technol. 122, 2000071(2020).

36) Gibon, V.; De Greyt, W.; Kellens, M. Palm oil refining. Eur. J. Lipid Sci. Technol. 109, 315-335(2007).

37) Ashaari, A.; Ahmad, T.; Awang, S.R.; Shukor, N.A. A graph-based dynamic modeling for palm oil refining process. Processes 9, 523(2021).

38) Alan, F.D.; Naeli, M.H.; Naderi, M.; Jafari, S.M.; Tavakoli, H.R. Production of trans-free fats by chemical interesterified blends of palm stearin and sunflower oil. Food Sci. Nutr. 7, 3722-3730 (2019).

39) Foster, R.; Williamson, C.; Lunn, J. Briefing paper: Culinary oils and their health effects. Nutr. Bull. 34, 4-47 (2009).

40) WFP (World Food Program). Technical specification for fortified refined bleached deodorized palm olein (2020) . https://docs.wfp.org/api/documents/WFP0000117612/download accessed on 16 March, 2021

41) Mukherjee, S.; Mitra, A. Health effects of palm oil. $J$. Hum. Ecol. 26, 197-203(2009).

42) May, C.Y.; Nesaretnam, K. Research advancements in palm oil nutrition: Highlight article Eur. J. Lipid Sci. Technol. 116, 1301-1315(2014).

43) Addis Fortune. Ethiopia: Government doubles exclusive palm oil importers to meet demand. Vol 20, No 1021 (2019). https://addisfortune.news/govt-doublesexclusive-palm-oil-importers-to-meet-demand accessed on 16 March, 2021

44) GAIN (Global Agriculture Information Network) and USDA (United States Department of Agriculture)Foreign Agricultural Service. Ethiopia Oilseeds Report Annual, Report Number: ET2021-0006 (2021).

45) IndexMundi(2021). Ethiopian palm oil imports by year. Available at https://www.indexmundi.com/agricul ture/?country=et\&commodity $=$ palm-oil $\&$ graph $=$ imports, Accessed on 2021, 9 July.

46) Agostoni, C.; Moreno, L.; Shamir, R. Palmitic acid and health: Introduction. Crit. Rev. Food Sci. Nutr. 56, 1941-1942 (2016).

47) Carta, G.; Murru, E.; Banni, S.; Manca, C. Palmitic acid: Physiological role, metabolism and nutritional implications. Front. Physiol. 8, 902 (2017).

48) Aggarwal, V.; Kashyap, D.; Sak, K.; Tuli, H.; Jain, A. et al. Molecular mechanisms of action of tocotrienols in cancer: Recent trends and advancements. Int. J. Mol. Sci. 20, 656 (2019).

49) Tholstrup, T.; Hjerpsted, J.; Raff, M. Palm olein increases plasma cholesterol moderately compared with olive oil in healthy individuals. Am. J. Epidemiol. 94, 1426-1432 (2011).
50) Xian, T.K.; Omar, N.A.; Ying, L.W.; Hamzah, A.; Raj, S. et al. Reheated palm oil consumption and risk of atherosclerosis: Evidence at ultrastructural level. Evid. Based Complement. Alternat. Med. 2012, 1-6 (2012).

51) Fattore, E.; Bosetti, C.; Brighenti, F.; Agostoni, C.; Fattore, G. Palm oil and blood lipid related markers of cardiovascular disease: A systematic review and metaanalysis of dietary intervention trials. Am. J. Clin. Nutr. 99, 1331-1350 (2014).

52) Go, R.-E.; Hwang, K.-A.; Kim, Y.-S.; Kim, S.-H.; Nam, K.-H.; Choi, K.-C. Effects of palm and sunflower oils on serum cholesterol and fatty liver in rats. J. Med. Food 18, 363-369 (2015).

53) Lucci, P.; Borrero, M.; Ruiz, A.; Pacetti, D.; Frega, N.G. et al. Palm oil and cardiovascular disease: a randomized trial of the effects of hybrid palm oil supplementation on human plasma lipid patterns. Food Funct. 7 , 347-354 (2016).

54) Sun, G.; Xia, H.; Yang, Y.; Ma, S.; Zhou, H. et al. Effects of palm olein and olive oil on serum lipids in a Chinese population: a randomized, double-blind, cross-over trial. Asia Pacific Journal of Clinical Nutrition 27, 572-580 (2018).

55) Baer David, J.; Henderson, T.; Gebauer Sarah, K. Consumption of high-oleic soybean oil improves lipid and lipoprotein profile in humans compared to palm oil blend: A randomized controlled trial. Lipids 56, 313325 (2021).

56) Gupta, S.V.; Ji, X.; Usman, A.; Razalli, N.H.; Sambanthamurthi, R. Oil palm phenolics (OPP) inhibit pancreatic cancer cell proliferation via suppression of NF-kB pathway. Anticancer Res. 35, 97-106 (2015).

57) Loganathan, R.; Radhakrishnan, A.K.; Selvaduray, K.R.; Nesaretnam, K. Selective anti-cancer effects of palm phytonutrients on human breast cancer cells. RSC Adv. 5, 1745-1753(2015).

58) Van Stuijvenberg, M.; Dhansay, M.; Lombard, C.; Faber, M.; Benadé, A. The effect of a biscuit with red palm oil as a source of $\beta$-carotene on the vitamin A status of primary school children: a comparison with $\beta$-carotene from a synthetic source in a randomized controlled trial. Eur. J. Clin. Nutr. 55, 657-662 (2001).

59) Loganathan, R.; Subramaniam, K.M.; Radhakrishnan, A.K.; Choo, Y.M.; Teng, K.T. Health-promoting effects of red palm oil: evidence from animal and human studies. Nutr. Rev. 75, 98-113(2017).

60) Qaim, M.; Sibhatu, K.T.; Siregar, H.; Grass, I. Environmental, economic, and social consequences of the oil palm boom. Annu. Rev. Resour. Econ. 12, 321-344. (2020).

61) Abrams, J.; Pischke, E.C.; Mesa-Jurado, M.A.; Eastmond, A.; Silva, C.A.; Moseley, C. Between environmental change and neoliberalism: The effects of oil 
palm production on livelihood resilience. Soc. Nat. Resour. 32, 548-565(2019).

62) Andrianto, A.; Komarudin, H.; Pacheco, P. Expansion of oil palm plantations in Indonesia's frontier: Problems of externalities and the future of local and indigenous communities. Land 8(4), 56-72 (2019).

63) Hariyadi, P. Food safety \& nutrition issues: Challenges and opportunities for Indonesian palm oil. IOP Conference Series: Earth and Environmental Science 418(1), 012003(2020).
CC BY-SA 4.0 (Attribution-ShareAlike 4.0 International). This license allows users to share and adapt an article, even commercially, as long as appropriate credit is given and the distribution of derivative works is under the same license as the original. That is, this license lets others copy, distribute, modify and reproduce the Article, provided the original source and Authors are credited under the same license as the original. (c) (i) (2) 